УДК 336.767.017.2

DOI: https://doi.org/10.26642/jen-2020-4(94)-11-21

Г.М. Тарасюк, д.е.н., проф.

О.П. Пащенко, к.е.н., доц.

І.В. Орлов, д.е.н., проф.

Н.П. Ігнатова, магістрант

Державний університет «Житомирська політехніка»

\title{
Підходи до дослідження інтелектуального капіталу на основі вартісно орієнтованого управління
}

\begin{abstract}
Чітка проєкція управління інтелектуальним капіталом з метою прирощення вартості в площину концепиії вартісно орієнтованого управління актуалізує дослідження в изьому напрямі. Досліджено питання підходів до структуризації інтелектуального капіталу підпиємства. Встановлено, щз інформаційною базою для вартісно орієнтованого управління інтелектуальним капіталом $\epsilon$ звітність підприємств, а точніше - інформація про нематеріальні активи підприємства. Уточнено, щзо відповідно до поділу інтелектуального капіталу на людський, структурний $i$ клієнтський не всі з наданих підвидів відображаються в звітних даних. Обгрунтовано, щз звітна інформація може бути представлена за допомогою як фінансових, так $i$ нефінансових показників, тому аналізувати слід як фінансову звітність, так $i$ управлінську, в якій може уточнюватися специфіка інтелектуального капіталу $i$ його компонентів. Визначено чотири підходи до дослідження інтелектуального капіталу на основі концепиії вартісно орієнтованого управління. А саме: 1) вартісно орієнтоване управління інтелектуальним капіталом; 2) оцінка (визначення) вартості інтелектуального капіталу; 3) управління вартістю інтелектуального капіталу; 4) інтелектуальний капітал як драйвер вартості підприємства. Запропоновано для подальших досліджень обирати проблематику вартісно-орієнтованого управління людським, структурним та клієнтським капіталом як складовими інтелектуального капіталу.

Ключові слова: вартісно орієнтоване управління; інтелектуальний капітал; вартість підприємства; управління вартістю; ринкова капіталізація; нематеріальні активи.
\end{abstract}

Актуальність теми. Управління інтелектуальним капіталом з метою прирощення вартості для підприємства чітко проєціює в площину концепції вартісно орієнтованого управління. Концепція «ValueBased Management» (VBM) або концепція вартісно орієнтованого управління, становлення якої відбувалося у 1980-1990рр. завдяки практиці провідних світових консалтингових компаній, з'явилася в умовах необхідності розробки стратегії, що забезпечувала б видимість корпоративних конкурентних потужностей, прозоро демонструвала результати відповідних заходів та надавала необхідну інформацію для прийняття ефективних рішень [11, с. 386]. Стратегія прирощення вартості - стратегія, яку обирають корпорації усього світу, тому пошук факторів створення вартості - це першочергова справа управлінців, які в своїх висновках грунтуються на системах інформації, сформованих як в самій компанії, так і ззовні - обставинами зовнішнього середовища. Інформація про інтелектуальний капітал підприємства знаходиться у фінансовій та нефінансовій звітності підприємства, але такі дані не є повними для розуміння та оцінки внеску інтелектуальної складової капіталу підприємства в загальний розмір його вартості. Тому дослідження проблематики вартісно-орієнтованого управління інтелектуальним капіталом підприємств є актуальним вектором для теоретичних напрацювань, що стануть підгрунтям для розвитку більш прозорого механізму управління та вдосконалення відповідної інформаційної бази.

Аналіз останніх досліджень і публікацій. Питаннями, що поєднують у собі проблематику інтелектуального капіталу та вартісно орієнтованого управління (чи управління вартістю), займалися такі українські дослідники, як Ю.А. Гороховець, І.М. Дрогобицький, О.О. Дядюн, О.В. Кендюхов, П.О. Куцик, С.Ф. Легенчук, К.А. Мамонов, М.О. Мельничук, О.Г. Мендрул, О.Б. Мних, З.П. Плиса, I.В. Прокопенко, Н.М. Проскуріна, В.С. Рудницький, Х.І. Скоп, О.М. Собко, О.О. Стрижак, Т.І. Хомуляк, I.Я. Яремко та інші.

Метою статті $є$ обгрунтування необхідності досліджень проблематики вартісно орієнтованого управління інтелектуальним капіталом підприємства шляхом уточнення розуміння цього напряму управління.

Викладення основного матеріалу. Забезпечення довгострокових конкурентних переваг підприємства шляхом ефективного управління інтелектуальним капіталом є сьогодні прерогативою функціонування суб'єктів господарювання в усьому світі. Управління інтелектуальним капіталом, що базується на основі концепції вартісно орієнтованого управління, спрямоване на прирощення вартості для підприємства. Тобто ефективність такого виду управління буде відображатися шляхом збільшення 
показників, які використовуються в межах реалізації концепції вартісно орієнтованого управління, а саме економічної доданої вартості (Economic Value Added, EVA), ринкової доданої вартості (Market Value Added, MVA), акціонерної доданої вартості (Shareholder Value Added, SVA), дохідності інвестицій на основі грошового потоку (Cash Flow Return on Investment, CFROI), грошової доданої вартості (Cash Value Added, CVA), динаміка яких тісно корелює з динамікою ринкової капіталізації.

На думку І.Й. Яремка [23, с. 311], конкурентні переваги сучасного суб'єкта ринкової економіки значною мірою споріднюються 3 наявністю і можливістю ефективного використання інформаційноінтелектуальних ресурсів. Такого типу ресурси також переважно впливають на вартість сукупного капіталу підприємства, видозмінюючи при цьому усталені поняття про вартість та цінність капіталу.

Відповідно до звіту СІМА, авторами якого $є$ Д.Старович і Б.Марр, для окремої фірми нерозуміння того, як генерується вартість, може призвести до неефективного розподілу ресурсів. Це означає, що компанія не повністю розуміє свою бізнес-модель і, отже, може бути не в змозі оцінити значущість майбутніх бізнес-можливостей. У більш широкому масштабі це може призвести до аномальної поведінки на ринку: якщо ринки не отримують потрібну їм інформацію за «офіційними» каналами, вони можуть вдаватися до чуток та спекуляцій, що може призвести до нестабільності. Також може статися неправильний розподіл ресурсів на макрорівні з точки зору ринкових інвестицій [7].

Як зазначають М.Р. Кабріта, В.С. Мачадо, А.Гріло [4, с. 237], у стратегічній перспективі знання, що створюють цінність, визначаються як інтелектуальний капітал, застосування якого дасть організаціям стійкі конкурентні переваги. Тому виявлення, вимірювання та управління інтелектуальним капіталом $€$ вирішальним для корпоративних інновацій та конкурентоспроможності. Вся складність вартісно орієнтованого управління інтелектуальним капіталом полягає в особливостях (природі) такого капіталу, що провокує проблему його неповного відображення в межах існуючої системи бухгалтерського обліку та звітності. Чинним законодавство (як вітчизняним, так і на міжнародному рівні) не передбачено чітку структуру інтелектуального капіталу підприємства. Найпоширенішим підходом до розуміння структури інтелектуального капіталу $є$ його бачення як сукупності людського, структурного та клієнтського капіталу. Його авторами вважаються Ю.Сент-Онж і Ч.Армстронг [6, с. 36].

Якщо детальніше розглядати зазначені вище структурні елементи інтелектуального капіталу, то слід зауважити наступне. Людський капітал підприємства являє собою систему продуктивних i комунікативних якостей, здібностей, сил, функцій та ролей людини, залучених до системи соціально орієнтованої економіки змішаного типу, сформованих і розвинутих у результаті інвестицій, що $\epsilon$ власністю носія капіталу. Вони використовуються в економічній діяльності, сприяють зростанню ефективності праці й доходів свого власника, підвищують додану вартість підприємства та моральне задоволення людини [15, с. 183]. Людський капітал представлений сукупністю інтелектуальних надбань та досвіду персоналу відповідного підприємства [10, с. 25]. Слід зазначити, що людський капітал підприємства не відображається в існуючій системі бухгалтерського обліку і звітності, тому в межах фінансової звітності можна знайти інформацію про середню кількість працівників за період, в межах нефінансової звітності - більш уточнюючу описову інформацію про працівників, їх структуру тощо. Для прикладу наведемо дані зі звітності американських компаній, які надають подібну інформацію (табл. 1).

Таблиия 1

Приклади даних про співробітників, щзо подаються у фінансовій звітності американських компаній

\begin{tabular}{|c|c|}
\hline Назва & Інформація, шьо подається \\
\hline 1 & 2 \\
\hline 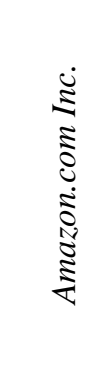 & $\begin{array}{l}\text { Станом на } 31.12 .2019 \text { р. у нас працювало приблизно } 798 \text { тис. штатних та неповних робочих } \\
\text { місць. Однак рівень зайнятості коливається через сезонні фактори, що впливають на наш } \\
\text { бізнес. Крім того, ми використовуємо незалежних підрядників та тимчасовий персонал для } \\
\text { доповнення нашої робочої сили. Ми маємо робочі ради, передбачені законодавством } \\
\text { зобов’язання щодо представництва працівників і профспілкові угоди в деяких країнах за } \\
\text { межами США та в деяких наших підрозділах у США. Ми вважаємо відносини з нашими } \\
\text { працівниками гарними. Конкуренція за кваліфікований персонал історично була напруженою, } \\
\text { особливо для інженерів програмного забезпечення, вчених у сфері інформатики та іншого } \\
\text { технічного персоналу }\end{array}$ \\
\hline
\end{tabular}


Закінчення табл. 1

\begin{tabular}{|c|c|}
\hline 1 & 2 \\
\hline & $\begin{array}{l}\text { На кінець фін. } 2019 \text { р. у Walmart Inc. та в наших дочірніх компаніях працювало понад } 2,2 \text { млн } \\
\text { співробітників (1,5 млн у США та } 0,7 \text { млн в інших регіонах). Подібно до інших роздрібних } \\
\text { торговців, Компанія має велику кількість співробітників, які працюють неповний робочий } \\
\text { день, погодинно чи без вилучення нарахувань. Ми вважаємо, що наші стосунки з нашими } \\
\text { співробітниками є гарними. Велика кількість співробітників щороку звільняється, хоча } \\
\text { ситуація з плинністю кадрів Walmart у США покращилась як у 2019, так і в } 2018 \text { фін. р., як } \\
\text { результат нашого зосередження на підвищенні заробітної плати та забезпеченні вдосконалених } \\
\text { інструментів, технологій та підгтовки співробітників. Певна інформація, що стосується } \\
\text { пенсійних виплат, які ми надаємо нашим співробітникам, включена в Примітки. На додаток до } \\
\text { пенсійних виплат, у США ми пропонуємо широкий спектр виплат, виплачуваних Компанією } \\
\text { нашим співробітникам. До них належать дисконтна картка магазину або членство в клубі } \\
\text { Sат’л, бонуси на основі результатів діяльності компанії, відповідність частини асоційованих } \\
\text { закупівель наших акцій через наш план придбання асоційованих акцій та страхування життя. } \\
\text { На додаток до медичних виплат працівникам, які мають право на повний та неповний робочий } \\
\text { день у США, ми пропонуємо відпустку у зв'язку з вагітністю та пологами і програму } \\
\text { оплачуваної батьківської відпустки для всіх штатних співробітників. Ми також пропонуємо } \\
\text { пільгу у розмірі } 5000 \text { дол. США, щоб допомогти співробітникам, які мають право на } \\
\text { усиновлення. Крім того, ми пропонуємо кваліфікованим спеціалістам допомогу у навчанні для } \\
\text { здобуття вищої освіти. Подібним чином під час діяльності за межами США ми надаємо } \\
\text { різноманітні асоційовані переваги, які варіюються залежно від звичної місцевої практики та } \\
\text { законодавчих вимог }\end{array}$ \\
\hline 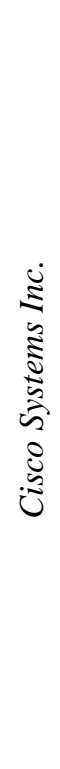 & 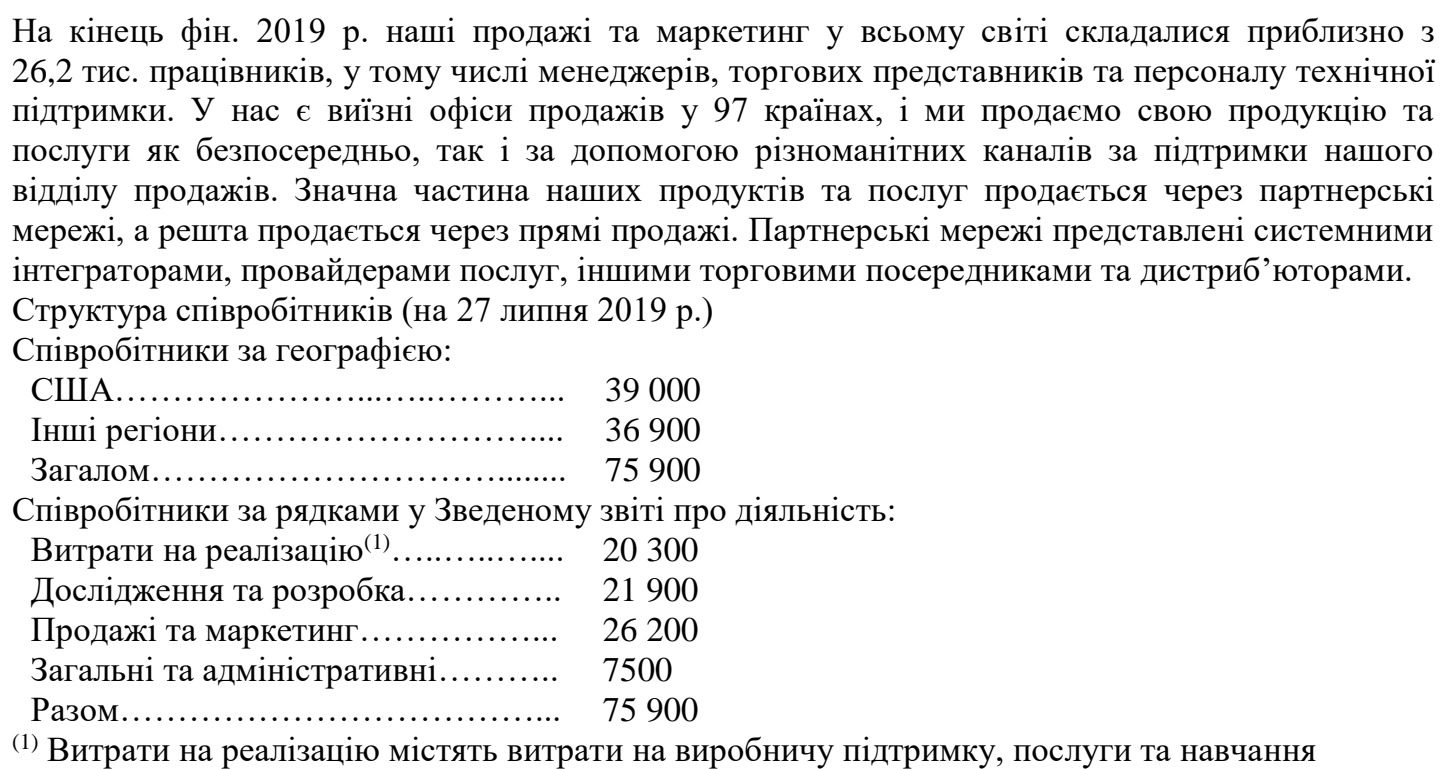 \\
\hline
\end{tabular}

Джерело: складено на основі [1, с. 13-14; 2, с. 5, 9; 3, с. 4]

Зазначені у таблиці 1 дані з фінансової звітності американських компаній дозволяють зрозуміти, що така інформація не дає чіткого уявлення про людський капітал компанії. У компанії «Amazon.com Inc.» така інформація має описовий характер, зокрема розкриваються питання кількості працюючих, наявності робочих рад та наявності такого фактора, як сезонність, що впливає на плинність кадрів компанії. У компанії «Walmart Inc.» дані розкриті дещо ширше: кількість працюючих (США / інші регіони світу), наявність працевлаштування на повний та неповний робочий день, проблема плинності кадрів та яким чином ведеться боротьба з нею, соціальні виплати та виплати як привілеї для співробітників компанії (наприклад, наявність виплат, якщо у співробітника $\epsilon$ право на усиновлення дитини), допомога у здобутті освіти тощо. У свою чергу компанія «Cisco Systems Inc.» наводить у власній фінансовій звітності таку інформацію про співробітників, як їх кількість, структура за географічним розміщенням та за специфікою того, до якого виду діяльності належить їхня діяльність, особливості каналів збуту тощо. Таким чином можна підсумувати, що всебічно і чітко охарактеризувати людський капітал цих компаній на основі подібної інформації з фінансової звітності складно через обмеженість даних. 
Під структурним капіталом необхідно розуміти різного роду інноваційні технології та інші продукти інтелектуальної діяльності, що створюють необхідні умови праці та визначають продуктивність людського капіталу. Цінність структурного капіталу виявляється тільки у взаємозв'язку з людським капіталом. Оскільки характерними ознаками сучасних підприємств $є$ вузька спеціалізація та комерційна таємниця, питома вага їх структурного капіталу може бути результатом власних досліджень та розробок $[10$, c. 25$]$.

Під клієнтським капіталом розуміють сукупність наявних клієнтських ресурсів (інформаційних, репутаційних, договірних, особистісних), одержаних в результаті інтелектуальної (творчої) діяльності, що забезпечують створення доданої вартості підприємства на основі системи відносин 3 клієнтами [12, с. 343-344]. У процесі свого розвитку поняття клієнтського капіталу розширилось від орієнтації на відносини 3 клієнтами до орієнтації на всіх стейкхолдерів підприємства, тим самим зумовивши появу нового поняття - клієнтського капіталу в широкому розумінні, який сьогодні дослідники називають реляційним або стейкхолдерським капіталом підприємства. Основними елементами кліснтського капіталу в широкому розумінні $є$ клієнти і відносини з ними, адже саме вони забезпечують генерування грошових потоків підприємства, надаючи можливість досягати поставлених завдань через посилення конкурентних позицій на ринку та отримання відповідних ефектів (прибуток, зростання ринкової вартості, залучення додаткових інвестицій тощо) [13, с. 51].

Проаналізувавши компоненти інтелектуального капіталу варто наголосити, що у людського, структурного та клієнтського капіталу є свої особливості як в аспекті процесів обгрунтування рішень щодо управління ними, так і відносно інформаційного супроводу, що має забезпечувати подібні процеси необхідними даними. Тому актуальним питанням для подальших досліджень буде вивчення проблематики вартісно орієнтованого управління в аспекті структурних елементів інтелектуального капіталу, а саме вартісно орієнтованого управління людським, структурним та клієнтським капіталом.

Також інтелектуальний капітал поділяють на активну та пасивну компоненту [22, с. 15-16]. Сутність активної складової інтелектуального капіталу підприємства (людський капітал) визначається на основі сутності людського капіталу, створеного на рівні індивіда, його здібностей, досвіду, навичок тощо. Пасивна складова інтелектуального капіталу підприємства - інтелектуальний продукт. У широкому розумінні ця категорія може бути представлена у вигляді реалізованих ідей, що втілюються у формі, доступній сприйняттю, розумінню й оцінці інших людей. Реально пасивна складова інтелектуального капіталу набуває вигляду новітніх технологій, методів, процесів, винаходів, торговельних марок тощо.

3 огляду на специфіку відображення інтелектуального капіталу в звітності, його можна поділити на 2 частини:

1) ідентифікована (об'єкти, які приносять підприємству економічні вигоди, чітко виокремлюються з загального обсягу інших об'єктів інтелектуального капіталу, можуть бути оціненими та прийнятими на баланс під власною назвою в якості нематеріальних активів);

2) неідентифікована (об'єкти, які приносять підприємству економічні вигоди, але не можуть бути взятими на облік як нематеріальні активи через їх невідокремлюваність від підприємства для подальшого комерційного використання і нездатність бути самостійним об'єктом угод).

Інтелектуальний капітал ідентифікують $з$ позиції набуття ним двох станів - змінного та постійного [10, с. 23-24]. Тому такий капітал можна поділяти на 2 частини - статичну та динамічну. Статична частина $\epsilon$ накопиченою інтелектуальною працею минулих періодів, яка бере участь у поточному виробництві як інтелектуальна складова уречевленої праці. До динамічної частини належить той людський капітал підприємства, який може бути зарахований до інтелектуального капіталу і який бере участь в процесі суспільного виробництва.

Тобто, інтелектуальний капітал можна уявляти як певну структуру, що складається:

1) 3 людського, структурного та клієнтського капіталу;

2) $з$ пасивної та активної частини;

3) 3 частини, що ідентифікується, та з частини, що не піддається ідентифікації;

4) зі змінного (динамічного) та постійного (статичного) капіталу.

В бухгалтерському обліку може бути відображений тільки ідентифікований інтелектуальний капітал.

Інформація про інтелектуальний капітал подається у звітності через категорію «нематеріальні активи» (intangible assets). Для прикладу наведемо дані щодо величини нематеріальних активів двадцятки компанійлідерів американського фондового ринку за величиною ринкової капіталізації на 31.12.2018 р. (табл. 2). 
Обсяг нематеріальних активів двадияткки найкращих * компаній американського фондового ринку за 2015-2019 рр. ** 
У розрізі абсолютного значення нематеріальних активів лідерами на 31.12 .2018 р. $з$ розглянутих компаній $є$ «AT\&T Inc.» (163827 млн дол. нематеріальних активів), «Verizon Communications Inc.» (103905 млн дол.), «Johnson \& Johnson» (47611 млн дол.), «Pfizer Inc.» (35211 млн дол.). Як показує практика звітування двадцятки компаній 3 найвищими показниками ринкової капіталізації на 31.12.2018 р. чітка загальна тенденція до зміни нематеріальних активів протягом досліджуваного періоду не спостерігається. Наприклад, компанія «Amazon.com Inc.» на 31.12.2018 р. мала 4,11 млрд дол. нематеріальних активів, що на 3,346 млрд дол. Більше, ніж на 31.12.2014 р. У відносному значенні частка нематеріальних активів у загальній величині активів для компанії «Amazon.com Inc.» зросла в 4,4 раза. Така тенденція не повторюється у більшості з представленого переліку компаній, що може пояснюватися специфікою функціонування самих компаній. Різні компанії мають різне насичення інтелектуальним peсурсом, зокрема компанія «Amazon.com Inc.» $\epsilon$ прикладом компанії 3 високим насиченням інтелектуального капіталу в аспекті специфіки своєї діяльності. Але досить важко робити подібні висновки без розуміння, яку частку загальних активів компанії складають саме нематеріальні. Проведемо такий аналіз на прикладі вже досліджуваної двадцятки найкращих компаній американського фондового ринку за величиною ринкової капіталізації на 31.12.2018 р. (табл. 3).

Табличя 3

Частка нематеріальних активів у загальній величині активів двадиятки найкращих компаній американського фондового ринку станом на 31.12.2018 p.

\begin{tabular}{|c|c|c|c|c|}
\hline $\begin{array}{c}\text { № } \\
\text { 3/n }\end{array}$ & Компанія & $\begin{array}{c}\text { Нематеріальні } \\
\text { активи, } \\
\text { млн дол. }\end{array}$ & $\begin{array}{c}\text { Активи } \\
\text { загалом, } \\
\text { млн дол. }\end{array}$ & $\begin{array}{c}\text { Частка нематеріальних } \\
\text { уагальній величині } \\
\text { активів, \% }\end{array}$ \\
\hline 1 & Apple Inc. & 0 & 365725 & 0 \\
\hline 2 & Microsoft Corp. & 8053 & 258848 & 3,11 \\
\hline 3 & Amazon.com Inc. & 4110 & 162648 & 2,53 \\
\hline 4 & Alphabet Inc. & 2220 & 232792 & 0,95 \\
\hline 5 & Facebook Inc. & 1294 & 97334 & 1,33 \\
\hline 6 & Johnson \& Johnson & 47611 & 152954 & 31,13 \\
\hline 7 & Exxon Mobil Corp. & 0 & 346196 & 0 \\
\hline 8 & Walmart Inc. & дані відсутні & 204522 & дані відсутні \\
\hline 9 & UnitedHealth Group Inc. & 9325 & 152221 & 6,13 \\
\hline 10 & Pfizer Inc. & 35211 & 159422 & 22,09 \\
\hline 11 & Boeing Co. & 3429 & 117359 & 2,92 \\
\hline 12 & Verizon Communications Inc. & 103905 & 264829 & 39,23 \\
\hline 13 & Chevron Corp. & 0 & 253863 & 0 \\
\hline 14 & AT\&T Inc. & 163827 & 531864 & 30,80 \\
\hline 15 & Intel Corp. & 11836 & 127963 & 9,25 \\
\hline 16 & Cisco Systems Inc. & 2552 & 108784 & 2,35 \\
\hline 17 & Merck \& Co. Inc. & 11431 & 82637 & 13,83 \\
\hline 18 & Procter \& Gamble Co. & 23902 & 118310 & 20,20 \\
\hline 19 & Home Depot Inc. & 0 & 44529 & 0 \\
\hline 20 & Coca-Cola Co. & 7007 & 83216 & 8,42 \\
\hline
\end{tabular}

Джерело: рейтинг сформовано за величиною ринкової капіталізації на 31.12.2018 p.

Проаналізувавши дані наведеної вище таблиці ми дійшли таких висновків. Нематеріальні активи у чотирьох компаній («Apple Inc.», «Exxon Mobil Corp.», «Chevron Corp.», «Home Depot Inc.») відповідно до даних їх звітності на 31.12.2018 р. були відсутні. Діапазон частки нематеріальних активів від 0 до $5 \%$ спостерігається у шістьох з представленого переліку компаній, а саме у «Microsoft Corp.», «Amazon.com Inc.», «Alphabet Inc.», «Facebook Inc.», «Boeing Co.», «Cisco Systems Inc.». Ще у трьох компаній («UnitedHealth Group Inc.», «Intel Corp.», «Coca-Cola Co.») діапазон частки нематеріальних активів у загальній величині активів становить від 5 до $10 \%$. Найбільші значення частки питомої ваги нематеріальних активів у цілому на 31.12 .2018 р. бачимо в «Merck \& Co. Inc.» $(13,83 \%)$, «Procter \& Gamble Co.» (20,20 \%), «Pfizer Inc.» (22,09 \%), «AT\&T Inc.» (30,80\%), «Johnson \& Johnson» $(31,13 \%)$, 
«Verizon Communications Inc.» (39,23 \%). Неможливо проаналізувати подібну частку нематеріальних активів для компанії «Walmart Inc.», адже ця компанія у власній звітності не відокремлює і подає об'єднану інформацію щодо величини нематеріальних активів та гудвілу.

Аналізувати величину нематеріальних активів без розуміння, які саме активи тут наведено, і які з них мають чітку проєкцію на такі структурні елементи інтелектуального капіталу, як людський, структурний та клієнтський капітал, не є прийнятним. Управління інтелектуальним капіталом у межах реалізації концепції вартісно орієнтованого управління вимагає прозорої інформаційної бази. На жаль, фінансова звітність як джерело інформації не задовольняє такі вимоги вартісно орієнтованого управління інтелектуальним капіталом.

Вартісно орієнтоване управління підприємством як гілка вартісних теорій є досить новою парадигмою у вивченні капіталізації бізнесу й визначає показник вартості як основний стратегічний орієнтир розвитку підприємства [18, с. 40-41]. Визначимо можливі варіанти використання вартісно орієнтованого управління відносно до інтелектуального капіталу підприємства (табл. 4).

Таблиияя 4

Варіанти використання вартісно орієнтованого управління відносно інтелектуального капіталу підприємства

\begin{tabular}{|c|c|c|c|c|}
\hline $\begin{array}{r}\text { Напрям } \\
\text { дослідження }\end{array}$ & $\begin{array}{c}\text { Вартісно } \\
\text { орієнтоване } \\
\text { управління } \\
\text { інтелектуальним } \\
\text { капіталом }\end{array}$ & $\begin{array}{c}\text { Очінка } \\
\text { (визначення) } \\
\text { вартості } \\
\text { інтелектуального } \\
\text { капіталу }\end{array}$ & $\begin{array}{c}\text { Управління } \\
\text { вартістю } \\
\text { інтелектуального } \\
\text { капіталу }\end{array}$ & $\begin{array}{c}\text { Інтелектуальний } \\
\text { капітал як } \\
\text { драйвер } \\
\text { вартості } \\
\text { підприємства }\end{array}$ \\
\hline Мета & $\begin{array}{c}\text { управління } \\
\text { інтелектуальним } \\
\text { капіталом, що } \\
\text { спрямоване на } \\
\text { генерування } \\
\text { (створення) } \\
\text { доданої вартості } \\
\text { для підприємства }\end{array}$ & $\begin{array}{c}\text { визначення } \\
\text { вартості } \\
\text { інтелектуального } \\
\text { капіталу }\end{array}$ & $\begin{array}{c}\text { управління } \\
\text { інтелектуальним } \\
\text { капіталом таким } \\
\text { чином, щоб } \\
\text { вартість його } \\
\text { збільшувалася }\end{array}$ & $\begin{array}{c}\text { побудова } \\
\text { механізму, який } \\
\text { би сигналізував } \\
\text { про те, який } \\
\text { внесок має } \\
\text { інтелектуальний } \\
\text { капітал у } \\
\text { загальну } \\
\text { величину } \\
\text { вартості } \\
\text { підприємства } \\
\end{array}$ \\
\hline $\begin{array}{c}\text { Об’єкт } \\
\text { дослідження }\end{array}$ & $\begin{array}{c}\text { сукупність } \\
\text { процесів } \\
\text { управління } \\
\text { інтелектуальним } \\
\text { капіталом } \\
\text { підприємства }\end{array}$ & $\begin{array}{c}\text { моделі } \\
\text { розрахунку } \\
\text { вартості } \\
\text { інтелектуального } \\
\text { капіталу }\end{array}$ & $\begin{array}{c}\text { вартість } \\
\text { інтелектуального } \\
\text { капіталу та } \\
\text { драйвери її } \\
\text { створення (чи } \\
\text { руйнування) }\end{array}$ & $\begin{array}{c}\text { процеси } \\
\text { створення } \\
\text { вартості для } \\
\text { підприємства } \\
\text { (в т. ч. і через } \\
\text { управління } \\
\text { інтелектуальним } \\
\text { капіталом) }\end{array}$ \\
\hline $\begin{array}{c}\text { Місце вартісно } \\
\text { орієнтованого } \\
\text { управління }\end{array}$ & $\begin{array}{c}\text { основа } \\
\text { управління, що } \\
\text { визначає його } \\
\text { основну мету - } \\
\text { прирощення } \\
\text { вартості для } \\
\text { підприємства }\end{array}$ & $\begin{array}{c}\text { одна з можливих } \\
\text { методик оцінки } \\
\text { вартості } \\
\text { інтелектуального } \\
\text { капіталу }\end{array}$ & $\begin{array}{c}\text { методика оцінки } \\
\text { вартості } \\
\text { інтелектуального } \\
\text { капіталу }\end{array}$ & $\begin{array}{c}\text { загальна } \\
\text { концепція } \\
\text { управління }\end{array}$ \\
\hline
\end{tabular}

Основними підходами до дослідження інтелектуального капіталу у межах реалізації концепції вартісно орієнтованого управління є: 1) вартісно-орієнтоване управління інтелектуальним капіталом; 2) оцінка (визначення) вартості інтелектуального капіталу; 3) управління вартістю інтелектуального капіталу; 4) інтелектуальний капітал як драйвер вартості підприємства.

Вартісно оріснтоване управління інтелектуальним капіталом покликане управляти інтелектуальним капіталом таким чином, щоб прирощувати вартість для підприємства. Тобто ефективність в цьому випадку буде корелювати зі збільшенням показників концепції вартісно орієнтованого управління, які у свою чергу тісно корелюють 3 ринковою капіталізацією підприємства. На думку О.Г. Мендрула [19, с. 44], наприклад, масштабні довгострокові інвестиції в інтелектуальний капітал об'єктивно призводять до зниження поточних прибутків, хоча забезпечують порівняно вищу 
прибутковість в майбутньому. Такі приклади, що спричиняють зниження поточної прибутковості, але в перспективі можуть прирощувати вартість для підприємства, мають досліджуватися у межах вартісно оріснтованого управління інтелектуальним капіталом.

Оцінка інтелектуального капіталу спрямована на визначення вартості такого капіталу. Вона обтяжена природою інтелектуального капіталу, адже інформація зі звітності про нематеріальні активи підприємства не дає повного розуміння величини інтелектуального капіталу. За словами О.В. Шкурупія [22, с. 147-148], оцінка компанії означає врахування не лише вартості технологій, а й «вартість» таких внутрішніх виробничих цінностей, як рівень досконалості управління персоналом і концепція поведінки підприємства у зовнішньому конкурентному середовищі. На думку автора, особливий вплив на ринкову вартість компанії має «ім'я» компанії, іiі імідж, довгострокові партнерські зв’ язки, постійність клієнтури, знання та компетентність співробітників, прагнення компанії та їі працівників до самовдосконалення і розвитку тощо.

Відповідно до положень методів оцінки ринкової капіталізації як одного з основних методів оцінки інтелектуального капіталу вартість інтелектуального капіталу розраховується як різниця між ринковою капіталізацією підприємства і власним капіталом [17, с. 178].

Унікальні об'єкти нематеріальних активів часто не враховуються в балансі, або їх облікова вартість $є$ значно нижчою за ринкову вартість, що призводить до заниження майнового стану підприємства. Причина такої ситуації - існуючі законодавчі обмеження щодо необхідності оцінки внутрішньо створених нематеріальних активів лише за первісною вартістю (собівартістю), без можливості приведення їх вартості до ринкової в момент їх створення. Існуюча бухгалтерська модель оцінки внутрішньо створених нематеріальних активів не дозволяє відобразити в бухгалтерській звітності повну і достовірну вартість тих елементів інтелектуального капіталу підприємства, які були прийняті як нематеріальні активи. Цим знижується майновий стан підприємства і ускладнюється процес управління нематеріальними активами як основними факторами створення вартості в умовах формування постіндустріальної економіки, що негативно впливає на потенційні дії інвесторів, які розглядають перспективи розвитку компанії і можливості отримання прибутку в довгостроковій перспективі [17, с. 178].

На думку I.В. Прокопенко [20, с. 216-217], вартісний еквівалент інтелектуального капіталу $є$ аморфним, його облікове значення визначається не стільки об'єктивними чинниками, як потребою підприємства продемонструвати свою спроможність генерувати стабільний грошовий потік, бути привабливим для інвесторів чи потенційних споживачів. Різниця між ринковою і балансовою вартістю підприємства може бути суттєвою, а нематеріальні активи мають властивість непрогнозованої зміни корисності, що є підставою для маніпуляцій під час їх оцінювання.

Зрозуміло, що інтелектуальний капітал оцінити складно, і тому з одного боку, може виникати недооцінка, що зумовить низку негативних наслідків для підприємства, а з іншого, «надування» вартості інтелектуального капіталу може бути інструментом маніпулювання управлінців задля корисних цілей висвітлення «бажаного» стану справ на підприємстві.

Управління вартістю інтелектуального капіталу передбачає таке управління, що спричиняє збільшення вартості такого виду капіталу. Управління вартістю нематеріальних активів - це робота 3 кожним видом інтелектуального капіталу і в той же час з усіма його видами, що забезпечує необхідну комбінацію людського та структурного капіталу [16, с. 198].

Такий підхід, як «Інтелектуальний капітал як драйвер вартості підприємства» передбачає побудову механізму, що сигналізував би про те, який внесок робить інтелектуальний капітал в загальну величину вартості підприємства, наприклад, періодично. Сутність інтелектуального капіталу як одного 3 видів капіталу полягає в можливості його залучення до процесу кругообігу, де здійснюється його інвестування, виробниче споживання та забезпечується додаткова вартість. Проте якщо порівнювати інтелектуальний капітал із відомими видами капіталу, то йому властиві значні ризики і більш високий ступінь розвитку, орієнтований на задоволення потреб суспільства. Крім того, в основі інтелектуального капіталу лежать юридичні права або права згідно з укладеними договорами, що свідчить про відсутність фізичної субстанції в них [21, с. 40]. Суть інтелектуального капіталу полягає у створенні вартості, яку можна розуміти як комплекс інтелектуальної власності, знань, навичок, процесів, досвіду та технологій, що використовуються підприємствами для забезпечення конкурентних переваг на ринку. Інтелектуальний капітал вимірює інтенсивність та результативність знань за допомогою чітко визначених структурованих показників [5, с. 502].

На думку О.Г. Мендрула [19, с. 30], особлива роль у створенні вартості належить інтелектуальному капіталу у формі нематеріальних активів - саме вони стають головним джерелом зростання вартості підприємств. Останнє пов'язане також зі збільшенням використання й інших факторів виробництва, при цьому всі фактори мають бути збалансовані як між собою, так і всередині себе між своїми складовими компонентами. Тобто з боку пропонування найбільше значення вартість має тоді, коли підприємством досягається оптимальна структура факторів виробництва; рівень оптимальності визначається межею, за якою збільшення будь-якого фактора не призводить до відповідного зростання вартості підприємства. 
Тому вектор досліджень щодо інтелектуального капіталу як одного з основних драйверів прирощення вартості для підприємства є актуальним та уможливлює розуміння важливості ролі невідчутних активів у стабільності та розвитку підприємства.

Отже, проблематика вартісно орієнтованого управління інтелектуальним капіталом підприємства охоплює досить багато аспектів, що необхідно теоретично опрацьовувати та апробовувати на практиці. У цій статті порушувалося питання основних підходів використання вартісно орієнтованого управління відносно інтелектуального капіталу підприємства та наголошувалося на важливості дослідження специфіки вартісно орієнтованого управління за структурними елементами інтелектуального капіталу людського, структурного та клієнтського капіталу.

Висновки та перспективи подальших досліджень. Основними підходами до структури інтелектуального капіталу підприємства є його поділ на: людський, структурний та клієнтський капітал; пасивну та активну частини; частину, що ідентифікується, та частину, що не піддається ідентифікації; змінний (динамічний) та постійний (статичний) капітал. Найприйнятнішою в аспекті обраного дослідження вважаємо поділ інтелектуального капіталу на такі складові, як людський, структурний та клієнтський капітал, причому слід зауважити, що у людського, структурного та клієнтського капіталу $є$ свої особливості як в аспекті процесів обгрунтування рішень щодо управління ними, так і відносно інформаційного супроводу, що має забезпечувати подібні процеси. Інформаційним забезпеченням вартісно орієнтованого управління інтелектуальним капіталом виступає звітність як фінансова, так i нефінансова, але складність полягає в тому, що звітні дані в межах діючого регламенту не дають чіткого та прозорого інформаційного підгрунтя для управління інтелектуальним капіталом підприємства. Вартісно орієнтоване управління інтелектуальним капіталом підприємства як інтеграція двох концепцій передбачає управління інтелектуальним капіталом, що спрямоване на генерування (створення) доданої вартості для підприємства, але це не єдиний підхід до дослідження інтелектуального капіталу підприємства на основі концепції вартісно орієнтованого управління. Окрім цього, нами ще виокремлюються такі підходи до дослідження інтелектуального капіталу на основі концепції вартісно орієнтованого управління як оцінка вартості інтелектуального капіталу, управління вартістю інтелектуального капіталу, інтелектуальний капітал як драйвер вартості підприємства. Перспективами дослідження вважаємо вивчення проблематики вартісно орієнтованого управління в аспекті структурних елементів інтелектуального капіталу, а саме вартісно орієнтованого управління людським, структурним та клієнтським капіталом.

\section{Список використаної літератури:}

1. Annual Report 2019 «Defining the Future of Retail» of Walmart Inc. [Electronic resource]. - Access mode : https://cutt.ly/sgYmSw8.

2. Annual Report 2019 «Defining the Future of the Internet» of Cisco Systems Inc. [Electronic resource]. - Access mode : https://cutt.ly/IgRCw8H.

3. Annual Report on Form 10-K of Amazon.com, Inc. for the year ended December 31, 2019 [Electronic resource]. Access mode : https://cutt.ly/kgRaeR6.

4. Cabrita M.R. Intellectual Capital: How Knowledge Creates Value / M.R. Cabrita, V.C. Machado, A.Grilo // Knowledge Management for Process, Organizational and Marketing Innovation. - New York : Information Science Reference, 2011. - P. 237-252.

5. Papula J. Intellectual Capital as Value Adding Element in Knowledge Management / J.Papula, J.Volna // In Proceedings of the International Conference Knowledge as Business Opportunity, Celje, Slovenia. - 2011. P. 497-504.

6. Saint-Onge H. The Conductive Organization: Building Beyond Sustainability / H.Saint-Onge, C.Armstrong // UK, Oxford : Elsevier Butterworth-Heinemann, 2004. - 249 p.

7. Starovic D. Understanding Corporate Value: Managing and Reporting Intellectual Capital / D.Starovic, B.Marr. CIMA, 2003 [Electronic resource]. - Access mode : https://cutt.ly/QgYEqrN.

8. 100 U.S. Stock Market Leaders // Stock Analysis on Net [Electronic resource]. - Access mode : https://www.stockanalysis-on.net.

9. Воропанова И.Н. Организационные технологии развития и использования интеллектуального капитала предприятия как ключевого фактора модернизации экономики : автореф. дис. на соискание науч. степени д.э.н. : спец. 05.02.22 «Организация производства в промышленности (экономические науки)» / И.Н. Воропанова ; Моск. акад. рынка труда и информац. технологий. - Челябинск, 2011. - 59 с.

10. Головай Н.М. Облік та аналіз в управлінні інтелектуальним капіталом підприємства : дис. на здобуття наук. ступеня к.е.н. : спец. 08.00.09 «Бухгалтерський облік, аналіз та аудит» / Н.М. Головай ; Київ. нац. торг.-екон. ун-т. - Київ, 2009. - 204 с.

11. Євдокимов В.В. Еволюція базових концепцій вартісно-орієнтованого управління / В.В. Євдокимов, Н.В. Валінкевич, Т.О. Завалій // Фінансово-кредитна діяльність: проблеми теорії та практики. - 2018. Вип. 3 (26). - С. 384-393.

12. Завалій T.O. Сутність поняття «клієнтський капітал»: підходи та структура / T.O. Завалій // Підприємницька модель економіки та управління розвитком підприємства : тези I Міжн. наук.-практ. конф., 8-9 лист. 2018 р. - Житомир : ЖДТУ, 2018. - С. 342-346. 
13. Завалій Т.О. Сутність та структура клієнтського капіталу: управлінський аспект / Т.О. Завалій // Проблеми теорії та методології бухгалтерського обліку, контролю і аналізу. - 2018. - Вип. 2 (40). - С. 19-27.

14. Ковтуненко К.В. Особливості обліку та оцінки інтелектуального фактору як фактору інноваційного розвитку промислового підприємства : монографія / К.В. Ковтуненко., Л.В. Скороходова. - Одеса, 2013. $126 \mathrm{c}$.

15. Кудлай А.В. Управління людським капіталом підприємства : дис. на здобуття наук. ступеня к.е.н. : спец. 08.09.01 «Демографія, економіка праці, соціальна економіка і політика» / А.В. Кудлай ; Харків. держ. екон. ун-т. - Харків, 2004. - 199 с.

16. Облікова концепція управління вартістю нематеріальних активів підприємства : монографія / П.О. Куциик, I.M. Дрогобицький, 3.П. Плиса, Х.I. Скоп. - Львів : Растр-7, 2016. - 268 с.

17. Легенчук С.Ф. Проблемы бухгалтерского учета интеллектуального капитала в Украине в Smartлогистических системах / С.Ф. Легенчук, Н.В. Деркач // Studia Universitatis Moldaviae. - 2019. - № 7 (127). C. $176-180$

18. Мельничук M.O. Бухгалтерський облік і контроль соціального капіталу торговельних підприємств : дис. на здобуття наук. ступеня к.е.н. : спец. 08.00 .09 «Бухгалтерський облік, аналіз та аудит» / М.О. Мельничук ; Харків. держ. ун-т харч. та торг. - Харків, 2019. - 234 с.

19. Мендрул О.Г. Управління вартістю підприємств: теоретичні та практичні аспекти : дис. на здобуття наук. ступеня д.е.н. : спец. 08.06.01 «Економіка, організація і управління підприємствами» / О.Г. Мендрул ; Київ. нац. екон. ун-т. - Київ, 2003. - 363 с.

20. Прокопенко I.B. Економічне оцінювання та регулювання інтелектуального капіталу машинобудівних підприємств : дис. на здобуття наук. ступеня к.е.н. : спец. 08.00.04 «Економіка та управління підприємствами» / I.B. Прокопенко ; Нац. ун-т «Львів. політехніка». - Львів, 2018. - 309 с.

21. Удосконалення системи бухгалтерського обліку, аналізу і контролю як інформаційного забезпечення управління суб'єктами господарювання : монографія / авт. кол. ; за ред. д.е.н., проф. В.С. Рудницького. Київ : ДВНЗ УБС, 2018. - 275 с.

22. Шкурупій O.B. Інтелектуальний капітал в умовах становлення постіндустріального суспільства: імперативи глобального економічного розвитку та орієнтири для України : монографія / O.B. Шкурупій. - Полтава : РВВ ПУЕТ, 2010. - $303 \mathrm{c}$.

23. Яремко І.Й. Публічна репрезентація інформаційно-інтелектуальної складової капіталу підприємства / I.Й. Яремко // Науковий вісник Ужгородського університету. Серія : Економіка. - 2015. - Вип. 1 (45). C. 311-316.

\section{References:}

1. Annual Report 2019 «Defining the Future of Retail» of Walmart Inc., [Online], available at: https://cutt.ly/sgYmSw8

2. Annual Report 2019 «Defining the Future of the Internet» of Cisco Systems Inc., [Online], available at: https://cutt.ly/IgRCw8H

3. Annual Report on Form 10-K of Amazon.com, Inc. for the year ended December 31, 2019, [Online], available at: https://cutt.ly/kgRaeR6

4. Cabrita, M.R., Machado, V.C. and Grilo, A. (2011), «Intellectual Capital: How Knowledge Creates Value», Knowledge Management for Process, Organizational and Marketing Innovation, Information Science Reference, New York, pp. 237-252.

5. Papula, J. and Volna, J. (2011), «Intellectual Capital as Value Adding Element in Knowledge Management», In Proceedings of the International Conference Knowledge as Business Opportunity, Celje, Slovenia, 22-24 June 2011, pp. 497-504.

6. Saint-Onge, H. and Armstrong, C. (2004), The Conductive Organization: Building Beyond Sustainability, Elsevier Butterworth-Heinemann, Oxford, UK, 249 p.

7. Starovic, D. and Marr, B. (2003), Understanding Corporate Value: Managing and Reporting Intellectual Capital, CIMA, [Online], available at: https://cutt.ly/QgYEqrN

8. Stock Analysis on Net, «100 U.S. Stock Market Leaders», [Online], available at: https://www.stock-analysis-on.net

9. Voropanova, I.N. (2011), «Organizatsionnye tekhnologii razvitiya i ispol'zovaniya intellektual'nogo kapitala predpriyatiya kak klyuchevogo faktora modernizatsii ekonomiki», Abstract of D.Sc. dissertation, spets. 05.02.22 Organizatsiya proizvodstva $\mathrm{v}$ promyshlennosti (ekonomicheskie nauki), Mosk. akad. rynka truda i informats. tekhnologii, Chelyabinsk, 59 p.

10. Golovaj, N.M. (2009), «Oblik ta analiz v upravlinni intelektual'nym kapitalom pidpryjemstva», Ph.D. Thesis of dissertation, spec. 08.00.09 Buhgalters'kyj oblik, analiz ta audyt, Kyi'v. nac. torg.-ekon. un-t, Kyi'v, 204 p.

11. Jevdokymov, V.V., Valinkevych, N.V. and Zavalij, T.O. (2018), «Evoljucija bazovyh koncepcij vartisnoorijentovanogo upravlinnja», Finansovo-kredytna dijal'nist': problemy teorii' ta praktyky, Issue 3 (26), pp. 384-393.

12. Zavalij, T.O. (2018), «Sutnist' ponjattja «klijents'kyj kapital»: pidhody ta struktura», Pidpryjemnyc'ka model' ekonomiky ta upravlinnja rozvytkom pidpryjemstva, tezy I Mizhn. nauk.-prakt. konf., 8-9 lyst. 2018 r., ZhDTU, Zhytomyr, pp. 342-346.

13. Zavalij, T.O. (2018), «Sutnist' ta struktura klijents'kogo kapitalu: upravlins'kyj aspekt», Problemy teorii' ta metodologii' buhgalters'kogo obliku, kontrolju i analizu, Issue 2 (40), pp. 19-27.

14. Kovtunenko, K.V. and Skorohodova, L.V. (2013), Osoblyvosti obliku ta ocinky intelektual'nogo faktoru jak faktoru innovacijnogo rozvytku promyslovogo pidpryjemstva, monografija, Odesa, $126 \mathrm{p}$. 
15. Kudlaj, A.V. (2004), «Upravlinnja ljuds'kym kapitalom pidpryjemstva», Ph.D. Thesis of dissertation, spec. 08.09.01 Demografija, ekonomika praci, social'na ekonomika i polityka, Harkiv. derzh. ekon. un-t, Harkiv, 199 p.

16. Kucyk, P.O., Drogobyc'kyj, I.M., Plysa, Z.P. and Skop, H.I. (2016), Oblikova koncepcija upravlinnja vartistju nematerial'nyh aktyviv pidpryjemstva, monografija, Rastr-7, L'viv, $268 \mathrm{p}$.

17. Legenchuk, S.F. and Derkach, N.V. (2019), «Problemy bukhgalterskogo ucheta intellektual'nogo kapitala v Ukraine v Smart-logisticheskikh sistemakh», Studia Universitatis Moldaviae, No. 7 (127), pp. 176-180.

18. Mel'nychuk, M.O. (2019), «Buhgalters'kyj oblik i kontrol' social'nogo kapitalu torgovel'nyh pidpryjemstv», Ph.D. Thesis of dissertation, spec. 08.00.09 Buhgalters'kyj oblik, analiz ta audyt, Harkiv. derzh. un-t harch. ta torg., Harkiv, 234 p.

19. Mendrul, O.G. (2003), «Upravlinnja vartistju pidpryjemstv: teoretychni ta praktychni aspekty», D.Sc. Thesis of dissertation, spec. 08.06.01 Ekonomika, organizacija i upravlinnja pidpryjemstvamy, Kyi'v. nac. ekon. un-t, Kyi'v, $363 \mathrm{p}$.

20. Prokopenko, I.V. (2018), «Ekonomichne ocinjuvannja ta reguljuvannja intelektual'nogo kapitalu mashynobudivnyh pidpryjemstv», Ph.D. Thesis of dissertation, spec. 08.00.04 Ekonomika ta upravlinnja pidpryjemstvamy, Nac. un-t «L'viv. politehnika», L'viv, 309 p.

21. Rudnyc'kogo, V.S. (ed.) (2018), Udoskonalennja systemy buhgalters'kogo obliku, analizu $i$ kontrolju jak informacijnogo zabezpechennja upravlinnja sub 'jektamy gospodarjuvannja, monografija, DVNZ UBS, Kyi'v, 275 p.

22. Shkurupij, O.V. (2010), Intelektual'nyj kapital v umovah stanovlennja postindustrial'nogo suspil'stva: imperatyvy global'nogo ekonomichnogo rozvytku ta orijentyry dlja Ukrai'ny, monografija, RVV PUET, Poltava, 303 p.

23. Jaremko, I.J. (2015), «Publichna reprezentacija informacijno-intelektual'noi' skladovoi' kapitalu pidpryjemstva», Naukovyj visnyk Uzhgorods'kogo universytetu, Serija Ekonomika, Issue 1 (45), pp. 311-316.

Тарасюк Галина Миколаївна - доктор економічних наук, професор, декан факультету бізнесу та сфери обслуговування Державного університету «Житомирська політехніка».

https://orcid.org/0000-0001-5112-102X.

Наукові інтереси:

- проблеми теорії та практики планування діяльності суб’єктів господарювання;

- управління проєктами;

- проблеми розвитку туризму та готельно-ресторанного бізнесу.

E-mail: galinatar@ukr.net.

Пащенко Ольга Петрівна - кандидат економічних наук, доцент кафедри менеджменту та підприємництва Державного університету «Житомирська політехніка».

https://orcid.org/0000-0002-5003-8977.

Наукові інтереси:

- проблеми теорії та практики менеджменту;

- проблеми розвитку підприємств на засадах маркетингу та креативного менеджменту.

E-mail: pashchenko.olga.2017@gmail.com.

Орлов Ігор Віталійович - доктор економічних наук, професор Державного університету «Житомирська політехніка».

Наукові інтереси:

- проблеми обліково-аналітичного забезпечення суб’єктів господарювання;

- методи оцінки інтелектуального капіталу.

Ігнатова Наталія Павлівна - магістрант Державного університету «Житомирська політехніка». Наукові інтереси:

- управління персоналом медичних закладів. 